\title{
The Temporal Structure of the Activities of Priests and the Substantive Effects of Religious Life in Contemporary Russia*
}

\author{
Nikolay Emelyanov \\ Archpriest, Researcher, Research Laboratory of the Sociology of Religion, \\ St. Tikhon's Orthodox University \\ Address: Lihov per., 6, str. 1, Moscow, Russian Federation 127051 \\ Email:pr_nikolay@mail.ru
}

\begin{abstract}
The article employs theoretical perspective of religious market to discuss the gap between the indicators of religious identification $(69 \%)$ and indicators of engagement in religious practices $(3 \%)$ in contemporary Russian society and the linked issue of insignificant influence of religiosity on population values and behavior according to mass surveys data. As the subsample of practicing Orthodox Christians demonstrates that religiosity has a very strong influence on values, marriages and reproductive behavior, rates of social diseases, etc. (I. Zabaev, E. Prutskova, D. Oreshina), the absence of religiosity effects in mass surveys data demands deeper investigation. Majority of studies interpret the gap between religious identification and participation in religious practices in the perspective of the secularization theory. We suggest reinterpretation of religious processes in Russia within the framework of the religious supply-side model. On the basis of the theory of religious economy (R. Stark, W. S. Bainbridge, R. Finke, L. Iannaccone, and others) we develop model of the religious market in the countries with religious monopoly. Depending on the average time spent on the confession, we model different evaluations of the religious market supply-side. Our analysis reveals that religious supply in Russia is significantly restricted by inaccessibility of given population of priests for regular participation in confession. The model of religious supply suggests the alternative to mainstream secularization discourse hypothesis for the explanation of the gap between Orthodox Christian identification and participation in confession and communion practices in contemporary Russia.
\end{abstract}

Keywords: measurements of religiosity, secularization, theory of religious market, model of religious supply, priest's time budget, social effects of religion, Russian Orthodox Church

\section{Introduction: The Problem of the Lack of Dynamics among Practicing Believers in the Russian Sociology of Religion}

The results of sociological studies carried out by the Institute of Socio-Political Research of RAS, the Russian Public Opinion Research Center (VCIOM), the Public Opinion Foundation (FOM), the Levada-Center, and others show a significant gap between those who identify themselves with Orthodox Christianity (between 60\% and 80\%, according to various surveys) and practicing church-going Orthodox Christians, estimated from $3 \%$ to $15 \%$ of the population regularly attending church services, going to confession,

\footnotetext{
(C) Nikolay Emelyanov, 2016

(c) Centre for Fundamental Sociology, 2016

DOI: $10.17323 / 1728-192 X-2016-4-176-201$

* The research was conducted within the framework of the program of the PSTGU Development Foundation in 2015-2016.
} 
and taking communion (Zorkaya, 2009; Kaariainen, Furman, 2007; Sinelina, 2006, 2013; Chesnokova, 2005).

Figure 1. Dynamics of those who consider themselves Orthodox Christians and those who regularly take Communion, 1991-2010 (Levada-Center, 2011)

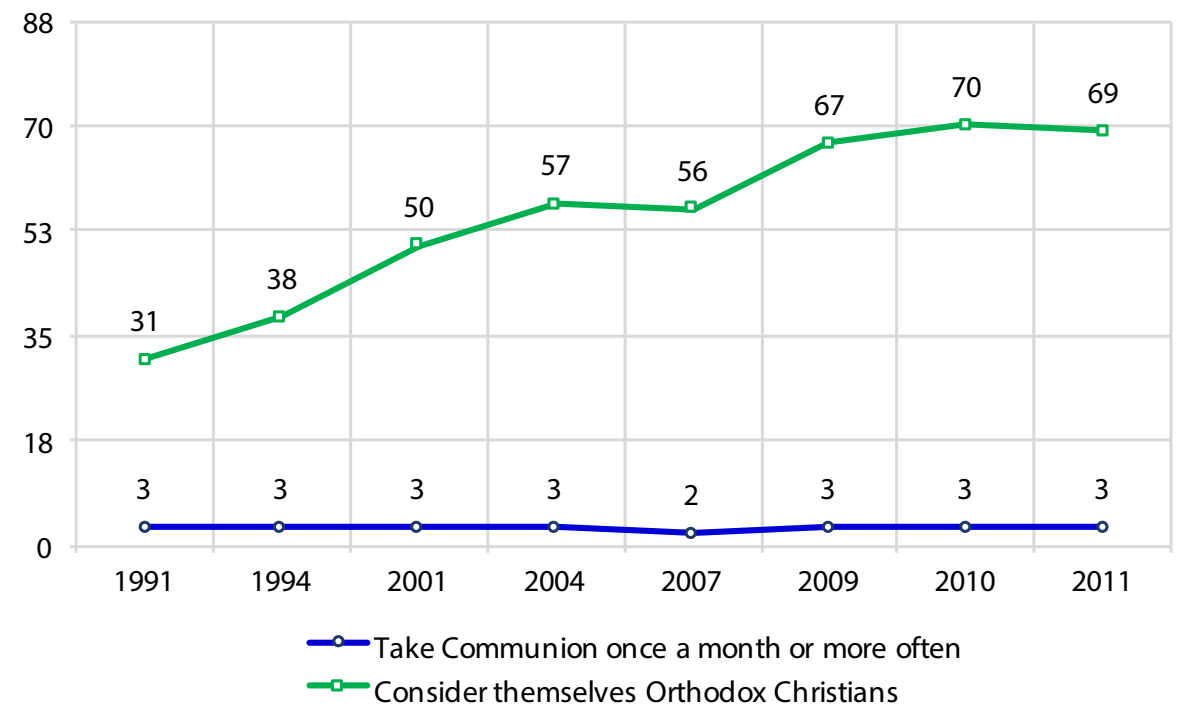

Considering that the number of priests in the Russian Orthodox Church has more than quadrupled from 6,674 in 1988 to 27,216 in 2008 , and the number of parishes has grown 4.25 times from 6,893 to 29,263 for the same period ${ }^{1}$, the simple explanation associated with the availability of parishes cannot be accepted as satisfactory.

The result seems to be rather negative in the cases when the studies included additional questions for detecting the influence of religion on other areas, since the impact of religiosity was practically indiscernible (Prutskova, 2015). The available analytical tools do not make it possible to observe the growing social importance of religion with a significant increase in religious self-identity.

The tendency taking hold in Russian sociology in explaining the growth of religious identity can be formulated in the following way: those who call themselves Orthodox Christians in Russia are not the actual believers. By calling themselves "Orthodox Christians," they rather indicate their identity as subjects of the state (Zorkaya, 2009: 65), and their national and ethnic identity. ${ }^{2}$ K. Kaariainen and D. Furman wrote about the "pro-

1. This number of priests in the entire canonical territory of the Russian Orthodox Church includes the Ukraine, Byelorussia, and the clergy serving in other countries (Kirill, Metropolitan of Smolensk, 2009).

2. Thus, V. Karpov, E. Lisovskaya, and D. Barry describe the phenomenon of "ethnodoxy," a mixed religious and ethnic identity typical for the Russians: "Ethnodoxy: a collectively held belief system that rigidly links a group's ethnic identity to its dominant faith" (Karpov, Lisovskaya, Barry, 2012: 644). 
Orthodox consensus," a positive attitude towards religion and the Russian Orthodox Church formed in the public consciousness, expressed in terms of confidence in the ROC and the growth of religious identity, but unaccompanied by an increase in religious practices and personal faith in God (Filatov, Lunkin, 2005: 44). M. Mchedlova noted some differences between Russian believers and non-believers, but these differences rarely transcended the boundaries of confidence intervals. This can also be explained by the gap between high level of self-identification with Orthodox Christianity and the low level of practicing religious life, which is behind this self-identification (Mchedlova, 2009: 83).

V. Lokosov and Y. Sinelina noted the validity of explaining confessional self-identity with socio-cultural and ethnic factors, but made the reservation that such theories did not account for the difference in the paces of quantitative and qualitative changes in the level of religiosity. They predict that the extensive capacity for growth in the level of religiosity in Russia is about to reach its limit, while the next step of intensive growth (the churching of the population, and engaging the population into religious practices) will require much more time. They write: “The level of religiosity has 'used up' the extensive capacity for growth and is reaching its natural limit, which, in our opinion, is about $80 \%$. Further intensive growth-the churching of the population-is beginning, which also has its limitations" (Lokosov, Sinelina, 2008: 137).

These explanations are based on the assumption of the secular nature of religious processes. Research of secularization in the twentieth century has led to the understanding of how both the term "secularization" and the processes designated by it are contradictory and ambiguous. By the 1970s, this notion became the ruling dogma in the sociology of religion. In the 1960s, B. Wilson defined secularization as "The process whereby religious thinking, practices and institutions lose their social significance” (Wilson, 1966: XIV). At the same time, Wilson's understanding of secularization transcends the scope of this definition, implying not only the loss of the social significance of religion, but also that the decline of faith that cannot evolve in the contemporary rationalized and pluralistic world. A similar position was expressed by P. Berger (Uzlaner, 2008).

By the end of the twentieth century, it became clear that the idea of the gradual disappearance of religion, the irreversibility of secularization, and the decline of religion depending on the degree of modernization of the society was absolutely wrong, and was refuted by indisputable facts (Berger, 2012). Secularization ceased to be understood as a global process which can give a universal answer to the question of the impact of modernity on religion. Moreover, it was becoming evident that it was necessary to raise the question of the reverse process of the influence of religion on the formation of modernity. S. Eisenstadt's concept of "multiple modernities" (Eisenstadt, 200o), based on the notion of the fundamental heterogeneity of modernity and its dependence on civilizational contexts, makes it impossible to simply place religious life into the secular worldview (Uzlaner, 2012: 22). An approach to the study of the correlation between modernity and religion from the viewpoint of the theory of rational choice (the theory of religious market) was offered in the late 1990s. This approach makes it possible to draw conclusions which are directly opposite to those which follow from the theory of secularization (see, 
for example, Stark, Bainbridge, 1987; Stark, Iannaccone, 1994). Unfortunately, this approach is not reflected in the Russian mainstream sociology of religion.

A more complex picture of the situation in Russia emerges from the studies of the internal mechanisms of religiosity. Following the ideas of R. Stark about religion as a "social structure" (Stark, 1996), E. Prutskova showed that early religious socialization ${ }^{3}$ had a significant impact on the fundamental values of European countries (Prutskova, 2013). Among European countries, Russia ranks last with its $6 \%$ level of early religious socialization. ${ }^{4}$ This fact gives grounds in suggesting that the social effects of religiosity can only result from a slow process of overcoming the consequences of forced secularization (Prutskova, 2015: 77).

The method of social network analysis (Zabaev, Prutskova, 2013; Zabaev, Oreshina, Prutskova, 2014) can demonstrate the importance of the social network of parish communities as an instrument of influence of religiosity on behavioral attitudes, including those outside of religious communities. The key factor is not the level of individual religiosity, but the strength of such connections, as well as the size and type of the social network of religious communities (Zabaev, Prutskova, 2013: 132). The study of strong Moscow communities (Zabaev, Oreshina, Prutskova, 2012: 37-40) shows that the influence of individual religiosity is particularly evident in the core and periphery of the community. ${ }^{5}$ This conclusion assesses the dynamics of religiosity in contemporary Russian society as a complex and slow process, directly dependent on the formation of church communities.

A discussion of the presence or absence of the social effects of religion in contemporary Russian society requires alternative approaches that takes both the specific measurements of Orthodox Christian religiosity in the Russian context, a set of factors which inhibit or facilitate the engagement of believers into religious practices, and the expression of social effects emerging from that religiosity into account. The development of such an approach is the goal of this article.

\section{Objectives}

This article is aimed at developing a model for assessing religious supply in Russia.

The main part of the article (1) provides an overview of the theory of religious economy and models for assessing religious supply in the countries with a competitive religious market and countries with religious monopoly; (2) describes the indicators which define

3. Early religious socialization was evaluated according to the practice of attending religious services at the age of 12. Such a question was asked in the European Values Study.

4. As opposed to $14 \%$ in Georgia, $62 \%$ in Western Germany, $63 \%$ in France, and $93 \%$ in Poland (European Values Study-2008).

5. Presently (in the early twenty-first century), the parish of an Orthodox Church can be divided into three parts: (1) the community core, (2) the community periphery, and (3) the extra-parochial Orthodox Christians. The three following groups of criteria can be applied in identifying a person as belonging to a specific part of a parish: (a) participation in religious practices (taking communion, attending church services, and so on), (b) self-identification as a member of the community, and (c) participation in the extra-liturgical activities of the parish (or awareness of them) (Zabaev, Oreshina, Prutskova, 2012: 7). 
the religious supply of the dominant confession in contemporary Russia (the number of priests and the orientation of the priestly action), as well as indicators of the level of the population's engagement in religious practices (going to confession and taking communion); (3) presents a model for assessing religious supply, depending on the type of parishioners and the average time of confession (communication with the priest). In the conclusion (4), we propose a hypothesis to explain the gap between the identification as Orthodox Christians and the engagement into the practices of confession and communion. In the section "Discussion," we will discuss the limitations and possible extensions of the proposed model.

\section{A Model for Assessing Religious Supply in Russia}

\section{Religious Economics: A Theory of Religious Mobilization and the Supply Model}

In the 1990s, R. Stark, R. Finke, W. Bainbridge, L. Iannaccone, S. R. Warner, and several other scholars proposed an approach to the study of the interrelation of modernity and religion, based on the theory of rational choice (Stark, Bainbridge, 1987; Stark, Iannaccone, 1994).The basis of this approach was the idea of religious market. Stark and Iannaccone introduced the concept of religious companies and religious economy: "Religious economy consists of all religious activities, operating in any society. Religious economies are like commercial economies in that they consist of a market of current and potential customers, a set of firms serving that market, and religious 'product lines' offered by various firms" (Stark, Iannaccone, 1994: 232). Additionally, the authors proposed the theory of religious mobilization consisting of seven assumptions describing religious economy, and placing the main emphasis on the behavior of "religious firms," not on "religious consumers." This makes it possible to assess the level of possible religious mobilization depending on the supply in the religious market. The main thesis of this theory is the assumption that "to the degree that a religious economy is competitive and pluralistic, overall levels of religious participation will tend to be high. Conversely, to the degree that a religious economy is monopolized by one or two state-supported firms, overall levels of participation will tend to be low" (ibid.: 233).

Preliminary testing of the model reveals that countries with high levels of regulation ${ }^{6}$ and high monopolization of the religious market ${ }^{7}$ show less religious engagement, simply operationalized as weekly church attendance (Stark, Iannaccone, 1994: 240-241).

6. M. Chaves and D. Cann evaluated the degree of regulation of religious economy in eighteen countries on the scale from o to 6, using six measuring items: "(a) there is a single, officially designated state church, (b) there is official state recognition of some denominations but not others, (c) the state appoints or approves the appointment of church leaders, (d) the state directly pays church personnel salaries, (e) there is a system of ecclesiastical tax collection, and (f) the state directly subsidizes, beyond mere tax breaks, the operating, maintenance, or capital expenses for churches" (Chaves, Cann, 1992: 280).

7. Monopolization of the religious market was operationalized by the Herfindahl Index which is applied to the economic analysis of markets. $\mathrm{H}=\mathrm{S}_{1}{ }^{2}+\mathrm{S}_{2}{ }^{2}+\ldots+\mathrm{SN}^{2}$, where $\mathrm{SX}$ is the share of those engaged in the Church $\mathrm{X}$ in the total amount of the engaged people in all Churches ("religious firms"), active in the given territory. The Herfindahl Index ranges between 1 and $1 / \mathrm{N}$, where $\mathrm{N}$ is the total number of Churches ("religious 


\section{A Model of Supply in the Conditions of Religious Monopoly}

The model of religious market describes the American situation well, where there is a zero index of religious market regulation, and a wide variety of competing Protestant Churches with an easy and repeated transition of adherents between the Churches throughout their lifetimes. However, there are some studies which give examples of the effective application of this model in countries with a rigid regulation of the religious market and a high degree of its monopolization. E. Hamberg and T. Pettersson use the model of religious market for studying the religious situation in Sweden (Hamberg, Pettersson, 1994). In 1990 the Church of Sweden was practically a monopolist in the religious market. Over $90 \%$ of the population considered themselves to be members of this Church, while only $4 \%$ went to church every week. Until 2000 the Church of Sweden was a state Church with very strong direct management and support.

In Sweden, 2,550 parishes distributed over 284 municipalities were taken as the units of analysis. In each municipality, the study evaluated (1) the number of religious services a year per capita and (2) the diversity of religious services. ${ }^{8}$ As a result, each parish and each municipality was distributed according to the following four types in relation to the median values across all parishes:

\begin{tabular}{c|c|c}
\hline & Few services & Many services \\
\hline $\begin{array}{c}\text { Dominated by traditional types } \\
\text { of services }\end{array}$ & $\begin{array}{c}\text { 1. Few and mostly traditional } \\
\text { services }\end{array}$ & $\begin{array}{c}\text { 2. Many and mostly traditional } \\
\text { services }\end{array}$ \\
\hline $\begin{array}{c}\text { Dominated by alternative } \\
\text { types of services }\end{array}$ & $\begin{array}{c}\text { 3. Few and varied types of } \\
\text { services }\end{array}$ & $\begin{array}{c}\text { 4. Many and varied types of } \\
\text { services }\end{array}$ \\
\hline
\end{tabular}

The level of engagement as a percentage of weekly church attendance in each municipality was taken as a dependent variable. The result showed a positive and stable dependence of the level of engagement from the type of municipality under controlled socio-economic indicators. The engagement was higher in the municipalities with many and more varied services per capita of the fourth type, and services not limited to the traditional types. ${ }^{9}$

firms"). The higher the Herfindahl Index is, the higher is the monopolization of the market. The index equals 1 in the conditions of absolute monopolization by a single "religious firm."

8. Both indicators-frequency and type of divine service-were rigorously recorded in official Church statistics. At the time of the study, the Church of Sweden had about ten different types of services which could be divided into traditional and alternative, introduced in a relatively recent times (Hamberg, Pettersson, 1994: 211).

9. The results of the analysis may cause many complaints and questions. The authors themselves recognized that one could not assert direct dependence of the level of demand on the level of supply. It is possible to interpret the data in the opposite direction: the variability of the supply is higher where the demand is higher. At the same time, the authors believe that in fact the supply precedes the demand, and it is possible to prove it (Hamberg, Pettersson, 1994: 213). 
Thus, the Russian situation of a gap between religious self-identity and religious practices is not unique in the world. According to Hamberg and Pettersson, the situation in Sweden in the late 1990's was characterized by an even more striking gap between the $90 \%$ of the population who affiliated themselves with the state Church of Sweden and the $4 \%$ of those who regularly attended divine service. G. Davie raises the problem of the reduction in the number of those attending church services in England, which is not accompanied by a drop in the number of believers (Davie, 1990). ${ }^{10}$

However, even with the external similarity of the situations in Russia and in some Western countries, the situations differ significantly. In addition to the differences in the content of religious life, it is obvious that the current religious situation in Russia remains strictly conditioned by the previous period of forced secularization associated with persecutions and ideological repressions. The application of concepts and approaches, elaborated for the countries of Western Europe and the Americas, requires caution and substantial clarifications.

\section{Indicators of the Model for Assessing Religious Supply in Russia}

The model of religious supply elaborated by Hamberg and Pettersson makes it possible to pose the question about the impact of religious supply on the level of engagement in religious practices of the dominant denomination, though requiring significant modifications.

A specific feature of the Russian Orthodox Church is that a significant indicator of religious supply is not the number of services or parishes, but the number of priests per capita of potential parishioners. Another scale for assessing religious supply will be not the variation of services, but the orientation of the priest toward the ministry or performing sacraments of the Church. The level of engagement is determined by the frequency of participation in the practices of confession and communion. ${ }^{11}$

Therefore, the model of religious supply for Russia should describe the level of engagement of believers of religious practices depending on two indicators, those of the number of priests, and the available time which the priest has for confession and conversations with people.

\section{Indicators of Parishioners' Engagement: Frequency of Going to Confession, Taking Communion, and Attending Church Services}

Russian sociology has several approaches to the classification of Orthodox Christian believers depending on the degree of their engagement in Church life. In accordance with

10. A. Day (2011) polemicizes with her.

11. This thesis is associated with two factors. Firstly, according to the practice of the Russian Orthodox Church, participation in the sacrament of communion is possible only after confession. Confession is administered only individually and requires personal communication with the priest. Secondly, taking communion is the indicative factor for assessing individual religiosity. Therefore, the possibility for individual communication with the priest and the priest's readiness for such communication is exactly the determining factor which limits the religious supply. The article will provide all necessary justifications and explanations below. 
the methodology of V. Chesnokova, believers can be divided into five groups based on five scales of being inchurched: going to church, going to confession and taking communion, reading the Gospels, praying, and keeping fasts (Chesnokova, 2005). The two scales of going to church and going to confession and taking communion differ in their content and method of measurement. These scales are associated with public worship and are frequency-oriented (once a month or more frequently, several times a year but less frequently than once a month, definitely once a year, rarely, occasionally, every few years, never in the age of reason). The other three scales describe individual practices and focus not on the frequency of specific religious practice, but on how it is expressed (Sinelina, 2013: 110).

Another typology of Orthodox Christian believers was proposed by Zabaev, Oreshina, and Prutskova (2012: 7-8). Based on the studies in the sociology of parishes in Europe and the USA (Oreshina, 2010a, 2010b), they proposed using three groups of criteria: (a) participation in religious practices (taking communion, attending church services), (b) self-identification as a member of the community, and (c) awareness about the life of the parish and lives of the parishioners. The authors identify three types of believers: community core, community periphery, and Orthodox Christians who are not a part of the parish community (Zabaev, Oreshina, Prutskova, 2012: 8). An important result was the discovery of the fact that a number of indicators, such as the behavior of the family, the share of those in a registered marriage, the number of children, the level of social diseases, and the understanding of patriotism, differ significantly from the general national numbers both in the core and in the periphery of the community (ibid.: 37-40). Again, the determining factor of this typology was the frequency of taking communion and attending church services, since even in the periphery of the community, the number of those who attended church services several times a year and more often was almost $98 \%$, and the number of those who took communion one to two times a year, or more often, was $76 \%$ (ibid.: 10-11).

These two indicators of attending church services and taking communion have rigid external constraints in terms of religious supply. Attending church services is rigidly restricted by the availability of a permanently operating church within walking distance, or at least within reach, with sufficient capacity regarding the potential number of parishioners.

Taking communion is only possible after confession, except in very rare cases of frequent communion (more than once a week) while maintaining a mandatory weekly confession. Confession may be very brief, but it always and fundamentally requires individual contact with the priest. ${ }^{12}$ Confession and communion are limited by the availability of priests, which primarily depends on the ratio of the number of priests to the number of parishioners.

12. See, "On the Participation of the Faithful in the Eucharist," approved at the Bishops' Council of the Russian Orthodox Church on February 3, 2015 (Russian Orthodox Church, 2015). 


\section{Indicators of Religious Supply: The Orientation of Priestly Actions and the Structure of a Priest's Time Budget}

From the perspective of religious supply, the opportunity for regular confession and communion requires an assessment of time-costs of the priest relative to the number of the parishioners. This assessment faces a number of challenges and can only be done on the basis of several important assumptions and limitations.

\section{TWO COMPONENTS OF PRIESTHOOD AND PRIESTLY ACTION}

Analysis of the current practice of confession shows its extraordinary complexity and diversity (see Vorobiev, 1997). Confession can take place in the church and outside of it, during and in connection with the church service, and outside of this connection. The practice of confession is highly dependent on the priest, his pastoral tradition, and even the practice of a specific church and community (see Vorobiev, 2000).

The analysis of confession is further complicated by the fact that it always involves some related actions and meanings. For example, confession, as a rule, involves subsequent communion, but not always. Moreover, such an association is not normative (Russian Orthodox Church, 2015). On the other hand, any pastoral action is always related to the issues of two principal components of priesthood, those of pastoral care and administration of the sacraments, ${ }^{13}$ which are always connected and related to each other. ${ }^{14}$ In

13. The Orthodox Christian understanding of the priesthood fundamentally emphasizes two of its sides, administering sacraments, and pastoral care: "The priesthood is the Sacrament in which the Holy Spirit entitles the correctly chosen [candidate] to administer the sacraments and shepherd (highlighted by the author) Christ's flock" (Filaret [Drozdov], 2006). Administering the Sacraments corresponds to the notion of the "appearance of Christ," when the priest acts only as a "servant of Christ" and the "agent of the Mysteries of God," whose true performer is Christ (1 Cor. 4: 1). Shepherding corresponds to the notion of "community leadership" and goes back to the Gospels' image of the shepherd and the flock of which the priest must "take heed" and "watch" (Acts 20: 28). Each of these aspects of priesthood is its integral component. The initial distinction between these two modes of action is associated with the accentuation of one of the components of the priesthood. The mode of action which focuses on performing divine service, administering Sacraments and prayers on request is based on the self-understanding of its function as the "manifestation of Christ" by the priest. A pastoral mode of action emphasizes the ministry, but first of all, the practice of pastoral care [lit. "care of souls"]. It is based on the understanding by the priest of his function in the Church as a "community leader."

14. Administering sacraments and pastoral care are two components of the priestly ministry, in a sense, orthogonal to each other. Administering sacraments determines the place of the priest in the Church, while pastoral care defines his position in the world. It is exactly the interaction of these two components that marks the specific action of the priest. While the administering of sacraments is objectified through the very notion of the sacrament and can be observed through the performance of a strictly defined set of rites, the definition of pastoral care raises serious difficulties. Pastoral care is associated with the management of the ecclesial community, that is, it includes the concept of authority and responsibility for the other, and can be carried out in relation to the individual person and the community as a whole. Pastoral action in relation to the individual person is usually referred to as dushepopechenie ("the care of souls"). The care of souls in the proper sense of the word refers to pastoral action (that is, the action produced by the authority of the priest and implying responsibility for the other): (1) active and conscious, (2) directed to a specific person (that is, entailing the establishment of personal relationship), (3) responding to this person's specific request (about his internal state or pain), (4) helping to solve a specific problem (aimed at his internal change), and (5) directed to the future (that is, implying continued personal relationship with the person in the prospect of his future life). It is easy to see that in this sense, any conversation of a priest with any person can, in practice, often have the nature of the "care of souls." Moreover, the care of souls can also be carried out without verbal communication. 
the situation of confession, these two components may, in a sense, become opposed to each other.

Confession is always a sacrament and its administration in the ecclesiastical consciousness has a self-sufficient and objective nature. ${ }^{15}$ An extreme manifestation accentuating the objective nature of this sacrament is the practice of "general confession." This practice originated and was possible only in extraordinary circumstances, ${ }^{16}$ and today is recognized as an unacceptable distortion of pastoral care (Vorobiev, 1997: 17). In that case, confession is reduced to a formal administering of the sacrament, which excludes the care of souls and personal contact with the priest. ${ }^{17}$

The opposite extreme of pastoral action in relation to confession is the so-called "mladostarchestvo," that is, the abuse of pastoral power manifested in an irresponsible emphasis on obedience to the priest. This practice has been repeatedly subjected to extremely harsh criticism of the church hierarchy. ${ }^{18}$ In this case, confession is reduced to a subjective communication with the priest excluding free participation in the sacrament which is understood as the personal standing before God.

\section{THE STRUCTURE OF A PRIEST'S TIME BUDGET}

Estimation of the time spent on an individual parishioner requires careful research into priests' time budgets. In addition, information about the structure of Orthodox Christian worship and cycles of Orthodox Christian life, as well as a number of previous and ongoing field studies ${ }^{19}$ allow us to make the following observations. These observations are associated with the structure of a priest's time budget and primarily depend on the organization of the service, and therefore can be generalized regardless of the specific features of the priest and parish. Quantitative evaluations of these time costs can significantly vary.

Constant parishioners who take communion more than once a month usually confess only in connection with the evening service on Saturday and the morning service on Sunday. Believers of this type tend to strictly observe the rule of compulsory attendance

15. In the sacrament of confession, "the person who confesses his sins, with the visible testimony (expression of will) of forgiveness from the priest, has his sins invisibly forgiven by the Lord Jesus Christ Himself" (Filaret [Drozdov], 2006).

16. This practice has emerged due to the obvious lack of priests and the persecution during the Soviet period (Vorobiev, 2000: 301-302).

17. By the very meaning of the sacrament, confession can only be individual. Its beginning is described in the Trebnik as follows: "The spiritual father brings the person who wants to confess alone, not two or many ..." (Moscow Patriarchate, 1991: 71). Cf., for example, Grigory (Chukov), Metropolitan, 1954.

18. The Holy Synod issued a special Statement 'On the cases of abuse of power to 'bind and loose' (Mat. 18:18) given to priests from God on the part of some priests, which has recently increased" (mospat.ru/archive/1999/o2/sr291281). See also the report of the Anniversary of the Bishops' Council of the Russian Orthodox Church, August 13-16, 2000 (mospat.ru/archive/page/sobors/200o-2/369.html).

19. We mean the data from the completed and ongoing empirical studies of the Sociology of Religion Laboratory at St. Tikhon's Orthodox University, such as the "Organization of Social Activities in the Parishes of the Russian Orthodox Church at the Beginning of the Twenty-First Century: Sociological Analysis" (20122013, supported by the Russian Foundation for Humanities), "Ways of Pastoral Action: Analysis of Priests' Time Budgets," and "The Liturgical Ledger of the Priest (Case Study)" (accomplished within the framework of Research Program of the Foundation for the Development of St. Tikhon's Orthodox University in 2016). 
of Saturday and Sunday services and, moreover, they come to the services of all major feasts. In this mode of attending divine service, it becomes almost impossible to come to the church regularly for confession at some other time.

Parishioners who take communion several times a year are divided into two groups. Some come to church only on major feasts, and thus the time for their possible confession is even shorter than for the previous group. Others feel uncomfortable (Zabaev, 2011) at services on major feasts due to the large number of parishioners in the church, and attend specially on weekdays, which is possible to combine with their working schedule several times a year.

Finally, those who take communion once a year or less can come to church any day, although a part of such parishioners come to church on the greatest annual feasts of the Nativity or Easter, when the time for confession is limited to the greatest extent.

The overwhelming majority of the priests serve in their parishes alone ${ }^{20}$ and are forced to conduct the divine service and hear confessions simultaneously, or set aside some time before and after the service for hearing confessions. In practice, this time is limited to 1 hour in the morning and 1 or 2 hours in the evening on weekdays. This time can be increased to 2 to 6 hours on Saturday nights, and remains 1 to 3 hours on Sunday mornings. In the conditions of the present-day parish, setting aside some special time for confession not associated with the divine service, does not exclude the need to hear confessions during the service or directly before the service from those who came to take communion.

THE UPPER BOUNDARIES OF A PRIEST'S TIME WHICH CAN BE ASSIGNED FOR CONVERSATIONS WITH PARISHIONERS DURING CONFESSION

The indicator "Priest's time available for conversations with the parishioners" imposes a very strict upper boundary on religious supply.

Regardless of the confession practice, pastoral tradition, specific features of worship schedules in a particular church, or its location and the type of settlement, we can roughly estimate the upper boundary of time which the priest can assign for hearing confessions.

For the group of permanent parishioners who take communion more than once a month, this time is estimated as the number of Sundays and feast days multiplied by the time possible for confession before communion on the very day of the feast and at the evening service of the previous day. This time amounts to not more than 335.5 hours a year. $^{21}$

20. By the beginning of 2011, the Russian Orthodox Church had 30,675 parishes and only 29,324 priests (Kirill [Gundyaev], Patriarch, 2012: 193).

21. 52 Sundays a year, 12 Great Feasts, 5 major feasts (specially designated in the official Church Calendar), and 3 revered feast days (the Kazan Icon of the Mother of God, two days of St. Nicholas); from 7 to 10 feasts, depending on the year, fall on Sunday. The priest may spend four Sundays and/or feast days on vacation, which gives us the total of 58 to 61 feast days. On each feast day, the priest may hear confession up to 4 hours on the eve of the feast day and up to 1.5 hours in the morning of the feast day, if the priest is alone. This gives us not more than $61 \times 5.5=335.5$ hours a year. 
For those who take communion several times a year, this time can be increased at the expense of weekdays up to 483 hours per year. ${ }^{22}$

For those who take communion once a year or less, this time may be hypothetically increased at the expense of the remaining working day of the priest during the weekdays. This will give an additional 547 hours per year. ${ }^{23}$

In fact, there will be even less time. A priest serving alone in a parish performs a number of duties which will never allow him to set aside that much time for church services and confession on weekdays. The calculation of time for holiday and Sunday worship and confession, which is associated with serving the liturgy in the morning and the all-night vigil on the previous evening of every Sunday and the days of church feasts and required of every priest, is only close to the real life situation.

\section{A Model for Assessing Religious Supply Depending on the Type of Parishioners and the Average Time of Confession}

An accurate assessment of time spent by the priest for hearing the confession of one parishioner depends on a number of factors. The most obvious factor is the frequency of confession. If a parishioner regularly communicates with the priest, confession can be very brief and does not entail any conversation with the priest at all. If even a short conversation is included into the confession, the confession cannot be shorter than 5-10 minutes. The confession of a person who has come to church for the first time in his life may last for 1-2 hours. Thus, the time of one confession may range from 0.5 minutes to 2 hours. It can vary considerably depending on whether the confession is associated with a request to give advice or consolation, to discuss a situation in life, etc. Such factors as gender, age, or psychological type of personality are of obvious importance. Therefore, in the model for assessing religious supply below, the ratio of the number of priests to the number of parishioners is calculated from various durations of one confession, which removes the problem of determining its real median value.

As one axis, we will take the variation in the time of confession: 1, 5, 15, 30, or 60 minutes.

22. The number of weekdays does not exceed 161. 365 days a year minus 58 feast days, 16 days of Bright Week and Christmas time, when regular confession is not performed; 2 days in the week before and 21 days during the Great Lent, when people cannot receive communion, 2 non-working days a week (except for 4 nonworking days on vacation, 7 weeks of the Great Lent and 2.5 weeks of the Bright Week and Christmas time, in total 77 days) and 30 days of vacation $(365-58-16-2-21-77-30=161)$. Time for hearing confessions is limited to 3 hours on weekdays, giving us not more than $161 \times 3=483$ hours a year.

23. In the proposed calculation, a weekday is composed of 2 hours of divine service (in the morning and in the evening) and 3 hours of hearing confessions (partially during the evening service). There remains 3 more hours of working time; 6 working days during 6 weeks of the Great Lent are added ( 2 non-working days, 4 days for divine service, and 1 day for receiving people) as well as 2 days in the week preceding the Great Lent (Wednesday and Friday), which were deducted in the calculation of weekdays, since there is no communion on these days. Therefore, they can be hypothetically considered as an 8-hour working day, during which the priest can receive parishioners. In total, this gives us $(161 \times 3)+(8 \times 8)=547$ hours a year. 
The other axis will represent different values of the number of parishioners, depending on the type of the parishioner: (1) those who take communion once a month or more frequently ( $2 \%$ of Orthodox Christians); (2) those who take communion several times a year, but less frequently than once a month (10\% of Orthodox Christians); (3) those who take communion once a year or once every few years (39\% of Orthodox Christians); (4) all those who identify themselves as Orthodox Christians and believers ( $73 \%$ of Orthodox Christians); (5) all those who identify themselves as Orthodox Christians ( $72 \%$ of respondents); (6) all of the ethnic Russian population of the Russian Federation, numbered at $111,017,000$ ethnic Russians out of the 142,857,000 population of the Russian Federation, according to the 2010 Census. ${ }^{24}$ Variations along this axis will be equal to $111,000,000$; 102,900,000; 75,900,000; 41,100,000; 40,100,000; 10,300,000, and 2,100,000 people.

Furthermore, we will construct the tables where the number of priests needed for hearing confessions from the number of parishioners in the given time will be indicated in the intersections of the rows and columns. In Table 1, these numbers were obtained on the assumption that all parishioners take communion once a year; in Table 3 (see Appendix), the numbers were obtained on the assumption that all parishioners take communion several times a year (the median value is taken equal to 6). In Table 4, the numbers were obtained on the assumption that all parishioners take communion once a month or more frequently (the median value is taken as equal to 24 times a year).

Table 1. The number of priests needed for speaking with the given number of people once a year, provided that each conversation takes a fixed amount of time from 1 min. to 1 hour

(it is assumed that the priest, being on permanent duty in the church on all weekly service days, continuously receives people, that is, at the rate of 1360.5 hours a year per priest)

\begin{tabular}{l|c|c|c|c|c|c}
\hline $\begin{array}{l}\text { "Those who take } \\
\text { communion once a } \\
\text { year" }\end{array}$ & $\begin{array}{c}\text { Thousands } \\
\text { of people }\end{array}$ & 1 min. & 5 min. & 15 min. & 30 min. & 1 hour \\
\hline 1. Russians & 111,017 & 1,360 & 6800 & 20,400 & 40,800 & 81,600 \\
\hline $\begin{array}{l}\text { 2. Orthodox Christians } \\
\text { (72\% of the population) }\end{array}$ & 102,857 & 1,260 & 6,300 & 18,901 & 37,801 & 75,602 \\
\hline $\begin{array}{l}\text { 3. Believers (73\% of } \\
\text { Orthodox Christians) }\end{array}$ & 75,086 & 920 & 4,599 & 13,797 & 27,595 & 55,190 \\
\hline $\begin{array}{l}4 . \text { Have never taken } \\
\text { communion (40\% of } \\
\text { Orthodox Christians) }\end{array}$ & 41,143 & 504 & 2,520 & 7,560 & 15,120 & 30,241 \\
\hline $\begin{array}{l}\text { 5. Once a year or less } \\
\text { frequently (39\% of } \\
\text { Orthodox Christians) }\end{array}$ & 40,114 & 491 & 2,457 & 7,371 & 14,742 & 29,485 \\
\hline $\begin{array}{l}\text { 6. Several times a year } \\
\text { (10\% of Orthodox } \\
\text { Christians) }\end{array}$ & 10,286 & 126 & 630 & 1,890 & 3,780 & 7,560 \\
\hline
\end{tabular}

24. The data is based on Sinelina, 2013: 105, 111. 


\begin{tabular}{l|c|c|c|c|c|c}
\hline $\begin{array}{l}\text { 7. Once a month of } \\
\text { more frequently (2\% of } \\
\text { Orthodox Christians) }\end{array}$ & 2,057 & 25 & 126 & 378 & 756 & 1,512 \\
\hline
\end{tabular}

Only 1360 priests are needed for hearing confession for 1 minute once a year for 111 million people (row 1, column "1 min."), provided that people would go to all priests in a uniform endless stream without stops and breaks for all days of the year, and at all times being free from performing religious services, without regard to any further workload of the priest. This is the roughest upper estimate, unrealistic in actual practice. In order to speak with each of 75 million Orthodox Christians who consider themselves believers once a year at least for half an hour, 27,595 priests are needed (row 3, column "30 min."). For hearing the first confession in a confessor's life for the duration of 1 hour from the 41 million Orthodox Christians who had never taken communion, 30,241 priests are needed (row 4, column " 1 hour"). Even for simply hearing confessions once a year for 15 minutes from those who take communion once a year or once every few years, 7,371 priests are needed (row 5, column “15 min.").

If we try to evaluate the same time costs in terms of the time which the priest can assign to liturgical service without regard to his time on duty in the church between services, the numbers become much higher (Table 2 in the Appendix). This estimate is much closer to reality than the estimates in the Table 1 . An army of 126,500 priests are needed for a one-hour conversation once a year with those who consider themselves Orthodox Christians.

To make it possible for all Orthodox Christian believers who attend church only several times a year to go to a priest for at least five minutes on the greatest feasts, 46,150 priests are needed (Table 3 of the Appendix). This is possible provided that all attendees are strictly distributed on Sundays and feast days of the Church Calendar, and the load on the priests is absolutely uniform. For hearing confessions for only 5 minutes from about 10 million people who take communion several times a year, 6,322 priests are needed.

For hearing confessions for 1 minute from those who take communion once a month or more frequently, only 2490 priests are needed (Table 4 of the Appendix). If we assume that those who take communion once a month or more frequently have the opportunity to speak with the priest for at least 5 minutes, this would require 12,499 priests (Table 4 of the Appendix; row 7 , column " 5 min."). The same opportunity of frequent confession for 5 minutes for those who take communion several times a year requires 62,243 priests. Finally, if we assume that all Orthodox Christians have the opportunity to come to church twice a month and speak with the priest for at least 5 minutes, 672,000 priests are needed.

We should mention that all estimates of priests' time costs are made in such a way that the required number of priests is underestimated in the proposed model, and all priests who receive people have an equal load. Nevertheless, even these estimates make it possible to formulate a number of hypotheses and remarks for discussion. 


\section{An Analysis of the Situation in Russia: A Hypothesis on the Reasons behind the Lack of Dynamics in Religious Practices}

The proposed analysis makes it possible to formulate a hypothesis which may explain both the gap between the practices of going to church and regular confession and communion, and the gap between the ever-growing religious self-identification and the absence of growth in religious practices.

Figure 2 shows a visualization of the model of supply. Straight lines show how many priests are needed for speaking to a given number of parishioners for a specified time interval. The graph shows the number of people who can converse with the priest at the current number of serving parish priests (the level is indicated by the dotted horizontal line). The vertical line on the graph at the intersection points with the slanted lines makes it possible to estimate how many priests are needed for hearing confessions at least once a month from the given number of people.

The graph clearly illustrates the gap between the number of serving priests and the number of priests required for engaging at least one-third of the believing population participating in the practices of regular confession and communion.

Figure 2. Model of religious supply for Russia

(the vertical axis shows the needed number of priests [thousands of persons];

the horizontal axis shows the time of confession [in minutes]. It is assumed

that priests hear confessions at all weekly and Sunday services [time budget 813.5 hours], and the parishioners are practicing believers (taking communion once a month)

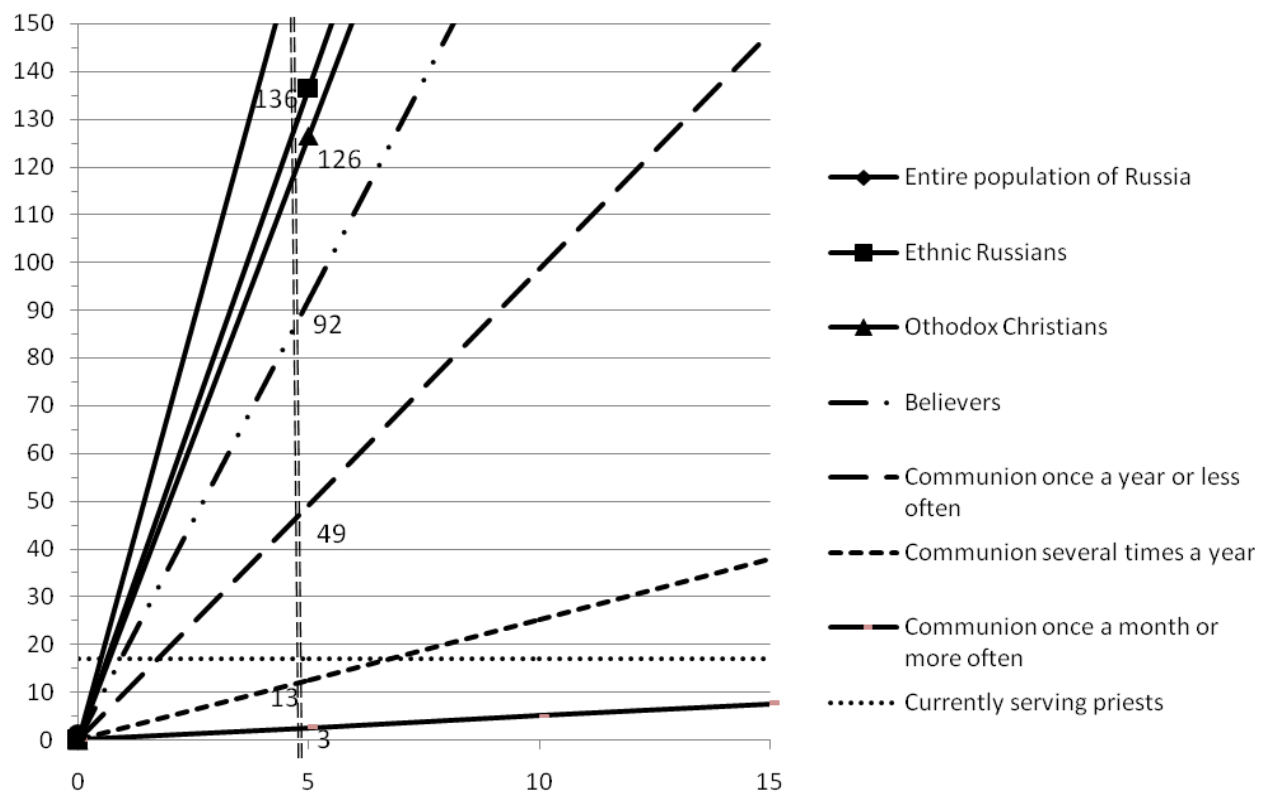


According to exaggerated estimates, no more than 17,000 priests ${ }^{25}$ currently serve in Russian parishes. Under the assumption that parishioners actually do not have an opportunity to speak with the priest, and confession is limited to 1 or 5 minutes, the number of the priests needed to meet the religious demand according to the proposed model is 12,921 . The required number of priests rises to 16,183 if we assume that those people coming to church for the first time, once every several years, or once a year speak with a priest for at least about 15 minutes. Finally, if we imagine that permanent parishioners who go to confession frequently are able to speak with a priest for at least 5 minutes, the required number of priests would reach 22,88o. ${ }^{26}$ There is an obvious gap between the existing number of priests and the number of priests needed for individual pastoral work. This gap must inevitably lead to a method of pastoral action aimed at providing religious services on demand ("treboispolnitel'stvo"), excluding personal contact and attention on the part of the priest, which has been repeatedly criticized by Church authorities. ${ }^{27}$

In response to the question "Do you know a priest whom you could turn to for advice in a difficult situation? And if you do know, is there one or several?" (Public Opinion Foundation (FOM), 2011), only 22\% of those who called themselves Orthodox Christians responded positively. According to our model, this roughly corresponds to the number of parishioners with whom 17,000 priests can speak at least once a year for 15 minutes on Sundays and feast days, when each participates in the services, and when the parishioners generally come to church.

The comparison of the ratio of parish priests and parishioners in various countries also shows that the number of clergy in Russia limits the opportunity for regular participation in parish life and in the main Christian sacraments of confession and communion. In 2014, in the USA, 76,700,00o people called themselves Catholics, and there were 38,275 Catholic priests ${ }^{28}$ (one priest per 2004 Catholics). According to the official report of the Catholic Church in Germany, the overall number of Catholics in 2013 was $24,170,754$ (29.9\% of the population), with 14,490 Catholic priests (including administrators and those on special assignments), which gives a ratio of 1:1168 (Deutschen Bischof-

25. Despite the difficulty of obtaining accurate statistics on the number of priests in Russia, we can use generalized data from the reports at the Bishops' Councils. The total number of priests $(29,324$ in 2011$)$ includes not only parish priests, but priests from monasteries (about a thousand priests reside only in stavropegial monasteries, that is, in the monasteries under direct administration of the Patriarch), as well as priests from the Ukrainian Orthodox Church, the Byelorussian Exarchate, and the foreign dioceses of the Russian Orthodox Church. If we deduct Ukrainian (about 10,00o) and Byelorussian (1485) priests, and monastery priests (about 1000), the total number of parish priests in Russia will not exceed 17,00o (Kirill [Gundyaev], Patriarch, 2012: 385; Vladimir, Metropolitan of Kiev and All Ukraine, 2011; Filaret, Metrolopitan of Minsk and Slutsk, 2012).

26. This number was obtained assuming that people who frequently take communion spend at least 1 minute for confession (Table 4 , row 7 , column " 1 min." = 2490), or 5 minutes (Table 4, row 7 , column “ 5 min." = 12,449); those who take communion several times a year spend 5 minutes on confession (Table 3, row 6, column "5 min." =6322), and those who take communion once a year or once every few years spend 5 minutes in confession during the time of the divine service (Table 2, row 5, column " 5 min." = 4109) or 15 minutes in the time when the service is not being performed (Table 2, row 5, column " 15 min." = 7371).

27. Kirill (Gundyaev), Patriarch, 2012: 277-278, 331; 2015: 21, 23-24, 25.

28. At the same time, only 66,600,00o people were affiliated with parishes (CARA, 2016). 
skonferenz, 2014: 12, 20). In Europe as a whole in 2012, this ratio was 1:2177 (CARA, 2015: 20). In Russia, this ratio is about $1: 6050^{29}$ (ibid.), and it is necessary to take a very different situation with uneven distribution, remoteness, and an inaccessibility of parishes into account as opposed to the case with Europe and the USA. ${ }^{30}$

The rapid growth in the number of clergy in the first twenty years after the fall of Soviet power essentially did not result in the growth in those churched believers who frequently take communion, apparently due to a very rapid growth of the groups of beginning believers. If so, the specific religious situation in Russia characterized by a low level of religious practices will persist for a sufficiently long time. To have the growth of practicing believers reach at least a statistically determinable $3 \%$, it is necessary to increase the body of clergy by 12,620 priests, that is, more than half as much the current number of priests.

With a stable growth of the body of the clergy, ${ }^{31}$ the prospects of a qualitative change in the situation cannot be expected earlier than twenty years, when and if the number of priests will reach 25,000-30,000. The number of priests in Russia needed for reaching the same ratio of priests to parishioners as the ratio in the USA is 51,000, requiring a $300 \%$ increase in the existing number of priests. As long as the situation with the accessibility of priests remains the same, which primarily depends on the number of parish clergy, there is every reason to believe that this limiting factor will be decisive for the formation of the religious situation in Russia, and the influence of religion on other areas of life will remain virtually imperceptible at the level of the quantitative surveys and statistical data.

\section{Discussion and Conclusions}

It is obvious that the proposed model does not account for many factors. The pastoral practice of each individual priest is not the same and is highly dependent on many factors, the main factors being the method of pastoral activities, the liturgical and extrachurch load, and the term of the priest's service.

In Western studies, the typology of priests explores the differences in the practice of pastoral care as one of the key factors of typology construction (Blizzard, 1985; Zulehner, 2001). Field studies of the priests of the Russian Orthodox Church also show a fundamentally different attitude toward pastoral care, its value, and place in the structure of

29. In 1915, the ratio of priests to the Orthodox Christian population of the Russian Empire was 1:2058, and the church authorities noted the lack of priests and churches. For comparison, in 1840, this ratio was 1:1203 (Orekhanov, Posternak, Terentieva, 1997: 206).

30. For example, in Moscow in 2015, weekly liturgical services were performed in 475 parishes with parish priests numbering 1,231, which gives the number of 17,400 Orthodox Christians per one permanently operating church, and 6730 Orthodox Christians per one priest. If we apply this pattern to those who call themselves Russians, this ratio will be 20,900 people per one church, and 8,066 people per one priest (according to the 2010 Census, the population of Moscow was 11,503,500, which gives a rough estimate of 8,282,500 Orthodox Christians) (Kirill [Gundyaev], 2015: 3).

31. In the three years from 2011 to 2013 , the number of priests increased from 29,324 to 30,340 , or $1.9 \%$ a year (Kirill [Gundyaev], Patriarch, 2013: 20). 
priest's time budget. ${ }^{32}$ Finally, the 2009 report of Patriarch Kirill at the Moscow Diocesan Assembly directly opposed the modes of priestly action, depending on different attitudes towards the practice of pastoral care. ${ }^{33}$ We may assume that there is a certain type of priest who practically does not provide pastoral care. ${ }^{34}$

The extra-church load can vary greatly depending on a variety of circumstances such as the participation of a priest in extra-liturgical activities, the number of services on demand, that is, the rites and sacraments performed outside the church at the request of parishioners, and other conditions of a priest's service. Even a superficial analysis of the ledgers with priests' time budgets shows that the differences in the structure of time budget and, accordingly, the difference in the time of confession or conversation with parishioners can vary greatly. ${ }^{35}$ In addition, it must be remembered that the vast majority of parish priests in the Russian Orthodox Church act as the administrative head of the parish, the Rector, ${ }^{36}$ which entails a very time-consuming engagement in administrative, organizational, financial, and economic issues.

Another significant factor is the type of settlement in which the parish is located, and the type of parish. ${ }^{37}$ The former factor obviously affects the hypothetically-possible size of the parish and the number of people in it. The latter factor is more complex. First of all, it is associated with the location of the parish in the settlement (Zabaev, Prutskova, 2012). Is it situated in an area with a large or small number of resident houses, near a transportation hub or away from it, near other frequently visited public places or far from them, as a separate building and on a separate territory, or on the territory of other organizations (for example, hospital or prison churches)? Depending on all factors, each parish is formed in a given church in various ways: permanent parishioners or constantly new people, a limited or a more-or-less constant but very broad circle of people, etc.

32. In the study "Patterns of Organizing Social Activities in the Parishes of Moscow" (2010), 32 interviews with priests and parishioners of Moscow and the Moscow region were taken. The interviews clearly demonstrated almost opposing attitudes towards pastoral practices. The main research results have been published in Zabaev, Oreshina, Prutskova, 2010.

33. In a special section, "General Question of Pastorship," administering religious services on demand is set against pastoral care ("the care of souls") (Kirill [Gundyaev], Patriarch, 2012: 277-278).

34. Such a type was described by the Protopriest Vladimir Vorobev as a relatively ordinary phenomenon of church life; "Certain passivism on the part of the spiritual father is traditional among us" (Vorobiev, 1997: 15).

35. In a study of the methods of pastoral action, five pilot weekly ledgers of the time budgets of Moscow priests were obtained through participant observation with subsequent interviewing. The results are striking and reveal completely different pastoral practices. One priest spent almost all his time in the church conversing with parishioners; the second priest participated in youth events and other parish activities; the third priest focused on Sunday school for adults; the fourth-a hospital priest-devoted a significant amount of time to giving communion and hearing confessions in the hospital, and the fifth priest spent most of his time at academic seminars and administrative meetings (N. Emelyanov, I. Zabaev, T. Krikhtova, D. Oreshina, "Ways of Pastoral Action: Analysis of Priests' Time Budgets." Research Project of the Sociology of Religion Laboratory at the St. Tikhon's Orthodox University, 2015).

36. In 2011, the Russian Orthodox Church had 29,324 priests, 30,675 parishes, and 805 monasteries (Kirill [Gundyaev], Patriarch, 2012: 193).

37. The typology of parishes is no less complex than the typology of priests (see Oreshina, 2010a, 2010b, 2014). 
Secondly, the type of parish ${ }^{38}$ significantly differs in terms of the time of existence (has never been closed, opened over a decade ago, recently opened, or an emerging parish), the number of clergy in the parish (a parish with several priests is organized fundamentally differently in terms of pastoral work than a parish with only one priest). A special type of parish and a special practice of pastoral care emerges in cathedrals where many official ecclesiastical events take place and festive services are performed. The parishes which are focused on a special ministry (hospital, prison, or military churches) have their own specific features.

All these factors can influence the structure of a priest's time budget and make it very difficult to more precisely assess the time for the "care of souls" available to each individual priest. It should be noted that all additional adjustments of the model only limit the hypothetically maximum available time which the priest would spend on the "care of souls," and thus only strengthens our main thesis on the insufficient number of priests and the limited religious supply in present-day Russia.

\section{Appendix}

Table 2. The number of priests need for speaking

with a given number of people once a year provided that each conversation

takes a fixed amount of time from $1 \mathrm{~min}$. to 1 hour

(it is assumed that the priest receives people only at Sunday, holiday, and weekday services immediately before and after the morning service and during the evening service, that is, at the rate of 813.5 hours a year per one priest)

\begin{tabular}{l|c|c|c|c|c|c}
\hline "Once a year" & $\begin{array}{c}\text { Thousands } \\
\text { of people }\end{array}$ & 1 min. & 5 min. & 15 min. & 30 min. & 1 hour \\
\hline 1. Russians & 111,017 & 2,274 & 11,372 & 34,117 & 68,234 & 136,468 \\
\hline $\begin{array}{l}\text { 2. Orthodox Christians } \\
\text { (72\% of the population) }\end{array}$ & 102,857 & 2,107 & 10,536 & 31,609 & 63,219 & 126,438 \\
\hline $\begin{array}{l}\text { 3. Believers (73\% of } \\
\text { Orthodox Christians) }\end{array}$ & 75,086 & 1,538 & 7,692 & 23,075 & 46,150 & 92,299 \\
\hline $\begin{array}{l}\text { 4. Have never taken } \\
\text { communion (40\% of } \\
\text { Orthodox Christians) }\end{array}$ & 41,143 & 843 & 4,215 & 12,644 & 25,288 & 50,575 \\
\hline $\begin{array}{l}\text { 5. Once a year or less } \\
\begin{array}{l}39 \% \text { of Orthodox } \\
\text { Christians) }\end{array}\end{array}$ & 40,114 & 822 & 4,109 & 12,328 & 24,655 & 49,311 \\
\hline
\end{tabular}

38. The existence and importance of these factors follows from the primary analysis of the data array obtained in two projects of the Sociology of Religion Laboratory at the St. Tikhon's Orthodox University. For the main results of the first project of 2011, "Three Parishes on the Feast of Protection," see Zabaev, Oreshina, Prutskova, 2012. The second study of 2012-2013 was titled "Organization of Social Activities in the Parishes of the Russian Orthodox Church at the Beginning of the 21st Century: Sociological Analysis." A series of in-depth interviews was conducted in fourteen parishes of the Russian Orthodox Church in the Moscow Region, Kaluga Region, Yaroslavl Region, Samara Region, Irkutsk Region, Altai Krai, Krasnoyarsk Krai, and Khabarovsk Krai (147 interviews in total). 


\begin{tabular}{l|c|c|c|c|c|c}
\hline $\begin{array}{l}\text { 6. Several times a year } \\
\text { (10\% of Orthodox } \\
\text { Christians) }\end{array}$ & 10,286 & 211 & 1,054 & 3,161 & 6,322 & 12,644 \\
\hline $\begin{array}{l}\text { 7. Once a month or } \\
\text { more frequently (2\% of } \\
\text { Orthodox Christians) }\end{array}$ & 2,057 & 42 & 211 & 632 & 1,264 & 2,529 \\
\hline
\end{tabular}

Table 3. The number of priests needed for speaking with a given number of people six times a year, provided that each conversation takes a fixed amount of time from $1 \mathrm{~min}$. to 1 hour

(it is assumed that the priest receives people only at Sunday, holiday, and weekday services immediately before and after the morning service and during the evening service, that is, at the rate of 813.5 hours a year per priest)

\begin{tabular}{l|c|c|c|c|c|c}
\hline "Several times a year" & $\begin{array}{c}\text { Thousands } \\
\text { of people }\end{array}$ & 1 min. & 5 min. & 15 min. & 30 min. & 1 hour \\
\hline 1. Russians & 111,017 & 13,647 & 68,234 & 204,703 & 409,405 & 818,810 \\
\hline $\begin{array}{l}\text { 2. Orthodox Christians } \\
\text { (72\% of the population) }\end{array}$ & 102,857 & 12,644 & 63,219 & 189,656 & 379,313 & 758,626 \\
\hline $\begin{array}{l}\text { 3. Believers (73\% of } \\
\text { Orthodox Christians) }\end{array}$ & 75,086 & 9,230 & 46,150 & 138,449 & 276,898 & 553,797 \\
\hline $\begin{array}{l}4 . \text { Have never taken } \\
\text { communion (40\% of } \\
\text { Orthodox Christians) }\end{array}$ & 41,143 & 5,058 & 25,288 & 75,863 & 151,725 & 303,450 \\
\hline $\begin{array}{l}\text { 5. Once a year or less } \\
\text { (39\% of Orthodox } \\
\text { Christians) }\end{array}$ & 40,114 & 4,931 & 24,655 & 73,966 & 147,932 & 295,864 \\
\hline $\begin{array}{l}\text { 6. Several times a year } \\
\text { (10\% of Orthodox } \\
\text { Christians) }\end{array}$ & 10,286 & 1,264 & 6,322 & 18,966 & 37,931 & 75,863 \\
\hline $\begin{array}{l}\text { 7. Once a month or } \\
\text { more frequently (2\% of } \\
\text { Orthodox Christians) }\end{array}$ & 2,057 & 253 & 1,264 & 3,793 & 7,586 & 15,173 \\
\hline
\end{tabular}

Table 4. The number of priests needed for speaking with a given number of people twenty-four times a year, provided that each conversation takes a fixed amount of time from $1 \mathrm{~min}$. to 1 hour (it is assumed that the priest receives people only at Sunday and holiday services immediately before and after the morning service and during the evening service, that is, at the rate of 335.5 hours a year per priest)

\begin{tabular}{l|c|c|c|c|c|c}
\hline $\begin{array}{l}\text { "Once a month or more } \\
\text { frequently" }\end{array}$ & $\begin{array}{c}\text { Thousands } \\
\text { of people }\end{array}$ & 1 min. & 5 min. & 15 min. & 30 min. & 1 hour \\
\hline 1. Russians & 111,017 & 134,362 & 671,812 & $2,015,437$ & $4,030,874$ & $8,061,749$ \\
\hline $\begin{array}{l}\text { 2. Orthodox Christians } \\
\text { (72\% of the population) }\end{array}$ & 102,857 & 124,487 & 622,433 & $1,867,299$ & $3,734,598$ & $7,469,195$ \\
\hline
\end{tabular}




\begin{tabular}{l|c|c|c|c|c|c}
\hline $\begin{array}{l}\text { 3. Believers (73\% of } \\
\text { Orthodox Christians) }\end{array}$ & 75,086 & 90,875 & 454,376 & $1,363,128$ & $2,726,256$ & $5,452,512$ \\
\hline $\begin{array}{l}\text { 4. Have never taken } \\
\text { communion (40\% of } \\
\text { Orthodox Christians) }\end{array}$ & 41,143 & 49,795 & 248,973 & 746,920 & $1,493,839$ & $2,987,678$ \\
\hline $\begin{array}{l}\text { 5. Once a year or less } \\
\text { frequently (39\% of } \\
\text { Orthodox Christians) }\end{array}$ & 40,114 & 48,550 & 242,749 & 728,247 & $1,456,493$ & $2,912,986$ \\
\hline $\begin{array}{l}\text { 6. Several times a year } \\
\text { (10\% of Orthodox } \\
\text { Christians) }\end{array}$ & 10,286 & 12,449 & 62,243 & 186,730 & 373,460 & 746,920 \\
\hline $\begin{array}{l}\text { 7. Once a month or } \\
\text { more frequently (2\% of } \\
\text { Orthodox Christians) }\end{array}$ & 2,057 & 2,490 & 12,449 & 37,346 & 74,692 & 149,384 \\
\hline
\end{tabular}

\section{Acknowledgements}

I wish to acknowledge the help provided by Elena Berdysheva, the first to read and edit the paper. Also, I would like to thank my colleagues from the "Sociology of Religion" Laboratory, and the research seminar "The Priesthood and Modernity" at St.Tikhon's Theological Institute, both who have provided me with invaluable comments on the article in the course of our seminars and informal discussions.

\section{References}

Berger P. (2012) Fal'sifitsirovannaya sekuliarizatsiya [Falsified Secularization]. State, Religion and Church in Russia and Worldwide, no 2, pp. 8-20.

Blizzard S. (1985) The Protestant Parish Minister: A Behavioral Science Interpretation, Storrs: The Society for the Scientific Study of Religion.

CARA (2015) Global Catholicism: Trends and Forecasts. Available at: http://cara.georgetown.edu/staff/webpages/Global\%20Catholicism\%2oRelease.pdf (accessed 26 December 2015).

CARA (2016) Frequently Requested Church Statistics. Available at: http://cara.georgetown.edu/frequently-requested-church-statistics/ (accessed 20 December 2016).

Chaves M., Cann D. E. (1992) Regulation, Pluralism, and Religious Market Structure: Explaining Religion's Vitality. Rationality and Society, vol. 4, no 3, pp. 272-29o.

Chesnokova V. (2005) Tesnym putem: protsess votserkovleniia naseleniia Rossii v kontse XX veka [Through the Narrow Way: The Process of Churching in Russia in the Late 2oth Century], Moscow: Akademicheskij proekt.

Day A. (2011) Believing in Belonging: Belief and Social Identity in the Modern World, Oxford: Oxford University Press.

Davie G. (1990) Believing without Belonging: Is This the Future of Religion in Britain? Social Compass, vol. 37, no 4, pp. 455-469. 
Deutschen Bischofskonferenz (2014) Katholische Kirche in Deutschland. Zahlen und Fakten 2013/14. Available at: http://www.dbk.de/fileadmin/redaktion/Zahlen\%2o und\%2oFakten/Kirchliche\%2oStatistik/Allgemein_-_Zahlen_und_Fakten/DBK_ Zahlen-und-Fakten2013-14_Internet.pdf (accessed 25 March 2015).

Eisenstadt S. (2000) Multiple Modernities. Daedalus, vol. 129, no 1, pp. 1-29.

Filaret, Metrolopitan of Minsk and Slutsk (2012) Doklad na Eparkhial'nom sobranii Minskoj eparkhii 05.01.2012 [Report at the Diocesan Assembly of the Minsk Diocese]. Available at: http://www.patriarchia.ru/db/text/1934395.html (accessed 24 March 2015).

Filaret (Drozdov), Svyatitel' (2006) Prostrannyj khristianskij katekhizis Pravoslavnoj Kafolicheskoj Vostochnoj Tserkvi [Expanded Christian Catechesis of the Orthodox Eastern Church], Moscow: Russian Orthodox Church.

Filatov S., Lunkin R. (2005) Statistika rossijskoj religioznosti: magiya tsifr i neodnoznachnaya real'nost' [Statistics of Russian Religiosity: The Magic of Numbers and Ambivalent Reality]. Sociological Studies, no 6, pp. 35-45.

Grigory (Chukov), Mitropolitan (1954) Tainstvo Pokayaniya i "obshchaia ispoved" [The Sacrament of Confession and the "Common Confession"]. Izbrannye rechi, slova $i$ stat'i [Selected Speeches, Words, and Articles], Leningrad.

Hamberg E. M., Pettersson Th. (1994) The Religious Market: Denominational Competition and Religious Participation in Contemporary Sweden. Journal for the Scientific Study of Religion, vol. 33, no 3, pp. 205-216.

Kaariainen K., Furman D. (2007) Religioznost' v Rossii na rubezhe XX-XXI stoletij [Religiosity in Russia at the Border of the 2oth and 21st Centuries]. Obshchestvennye nauki i sovremennost', no 1, pp. 103-119, no 2, pp. 78-95.

Karpov V., Lisovskaya E., Barry D. (2012) Ethnodoxy: How Popular Ideologies Fuse Religious and Ethnic Identities. Journal for the Scientific Study of Religion, vol. 51, no 4, pp. 638-655.

Kirill, Metropolitan of Smolensk (2009) Report at the Local Council of the Russian Orthodox Church, January 27, 2009. Availabale at: http://www.patriarchia.ru/db/ text/541724.html (accessed 29 December 2015).

Kirill (Gundyaev), Patriarch (2012) Slovo Predstoiatelia (2009-2011): sobranie trudov. Tom 1 [The Word of the Primate (2009-2011): Collected Works, Vol. 1], Moscow: Moscow Patriarchate.

Kirill (Gundyaev), Patriarch (2013) Doklad na Arkhiereiskom Sobore 2 fevralia 2013 goda [Report on The Hierarchal Council 2.02.2013]. Zhurnal Moskovskoi Patriarkhii, no 3, pp. 6-25.

Kirill (Gundyaev), Patriarch (2015) Doklad na Eparkhial'nom sobranii g. Moskvy 2015 goda (21.12.2015) [Report at the Moscow Diocesan Assembly of 2015 (21.12.2015). Available at: http://www.patriarchia.ru/data/2015/12/22/1238870485/doklad\%202015. docx (accessed 16 September 2015).

Orekhanov Y., Posternak A., Terentieva T. (1997) Kratkij statisticheskij obzor uslovij religiozno-prosvetitel'skoj deyatel'nosti Rossijskoj Pravoslavnoj Tserkvi pri izmenivsh- 
emsya ustrojstve Rossii i po otdelenii Tserkvi ot gosudarstva [Short Statistic Overview of Conditions for Religious-Educational Work of the Russian Orthodox Church after the Changed Structure of Russia and after the Separation of the Church from the State]. Bogoslovskij sbornik, no 1, pp. 195-236.

Levada-Center (2011) Religioznaya vera v Rossii [Religious Faith in Russia]. Available at: http://www.levada.ru/2011/o9/26/religioznaya-vera-v-rossii (accessed 23 March 2016).

Lokosov V., Sinelina Y. (2008) Vzaimosvyaz' religioznykh i politicheskikh orientatsij pravoslavnykh rossiyan [Correlation between Religious and Political Orientation of the Orthodox Christian Russians]. Religiya v samosoznanii naroda (religioznyj faktor v identifikatsionnykh protsessakh) [Religion in the Self-Consciousness of the People (Religious Factor in Identification Processes)] (ed. M. Mchedlova), Moscow: Institut sotsiologii RAN, pp. 135-158.

Mchedlova M. (2009) Rol' religii v sovremennom obshchestve [Role of Religion in the Contemporary Society]. Sociological Studies, no 12, pp. 77-84.

Oreshina D. (2010a) Katolicheskii prikhod vo vtoroj polovine XX veka: faktory formirovaniya prikhodskoj obshchiny [Catholic Parish in the Second Half of the 2oth Century: Factors for Forming the Parish Community]. Available at: http://socrel.pstgu.ru/wp-content/uploads/2013/o9/WP_2010-03.pdf (accessed 29 December 2015).

Oreshina D. (2010b) Prikladnye sotsiologicheskie issledovaniya katolicheskogo prikhoda v SShA do reform Vtorogo Vatikanskogo sobora (1962-1965 gg.) [Applied Sociological Studies of the Catholic Parish in the USA before the Reforms of the Second Vatican Council]. Available at: http://socrel.pstgu.ru/wp-content/uploads/2013/o9/WP_201004.pdf (accessed 29 December 2015).

Oreshina D. (2014) Sotsial'naya deyatel'nost' prikhodskikh obshchin i konfessional'nykh organizatsii: obzor sotsiologicheskikh issledovanii [Social Activity of Parish Communities and Confessional Organizations: Overview of Sociological Studies]. Available at: http://socrel.pstgu.ru/wp-content/uploads/2014/12/WP_2014-14.pdf (accessed 29 December 2015).

Prutskova E. (2013) Religioznost' i ee sledstviia v tsennostno-normativnoj sfere [Religiosity and Its Consequences in the Value-Normative Sphere]. Sociological Studies, no 2, pp. $72-88$.

Prutskova E. (2015) Sviaz' religioznosti i tsennostno-normativnykh pokazatelei: faktor religioznoi sotsializatsii [Connection of Religiosity with Value-Normative Characteristics: The Factor of Religious Socialization]. Vestnik PSTGU. Series I: Theology. Philosophy, no 3, pp. 62-80.

Russian Orthodox Church (2015) Ob uchastii vernykh v Evkharistii. Priniat na Arkhiereiskom Soveshchanii Russkoi Pravoslavnoi Tserkvi 3.02.2015 g. [On the Participation of the Faithful in the Eucharist. Adopted at the Bishops' Conference of Russian Orthodox Church on February 3, 2015]. Available at: http://www.patriarchia.ru/db/ text/3981166.html (accessed 29 December 2015). 
Sinelina Y. (2006) Izmerenie religioznosti naseleniia Rossii: pravoslavnye i musul'mane: suevernoe povedenie rossiian [Measurement of People's Religiosity in Russia: Muslims and Orthodox Christians: The Superstitious Behavior of the Russians], Moscow: Nauka.

Sinelina Y. (2013) O dinamike religioznosti rossiyan i nekotorykh metodologicheskikh problemakh ee izucheniya (religioznoe soznanie i povedenie pravoslavnykh i musul'man) [On the Dynamics of Religiosity of Russians and Some Methodological Problems of Its Research (Religious Consciousness and Behavior of the Orthodox Christians and Muslims)]. Sociological Studies, no 10, pp. 104-115.

Stark R. (1996) Religion as Context: Hellfire and Delinquency One More Time. Sociology of Religion, vol. 57, no 2, pp. 151-163.

Stark R., Bainbridge W. S. (1987) A Theory of Religion, Bern: Peter Lang.

Stark R., Iannaccone L. (1994) A Supply-Side Reinterpretation of the "Secularization" of Europe. Journal for the Scientific Study of Religion, vol. 33, no 3, pp. 230-252.

Moscow Patriarchate (1991) Trebnik [Book of Needs], Moscow: Moscow Patriarchate.

Uzlaner D. (2008) Sekulyarizatsiya kak sotsiologicheskoe ponyatie (po issledovaniyam zapadnykh sotsiologov) [Secularization as a Sociological Notion (Based on the Studies of Western Sociologists]. Sociological Studies, no 8, pp. 62-67.

Uzlaner D. (2012) Ot sekuliarnoi sovremennosti k "mnozhestvennym": sotsial'naia teoriia o sootnoshenii religii i sovremennosti [Form Secular Modernity to "Plural" Modernities: Social Theory on the Correlation of Religion and Modernity]. State, Religion and Church in Russia and Worldwide, no 1, pp. 14-19.

Vladimir, Metropolitan of Kiev and All Ukraine (2011) Ukrainskaya Pravoslavnaya Tserkov' segodnya. Doklad na Arkhierejskom Sobore Pravoslavnoj Tserkvi 4.01.2011 g. [Ukrainian Orthodox Church Today. Report at the Bishop's Council of the Orthodox Church, January 1, 2011]. Available at: http://www.patriarchia.ru/db/text/1401848. html (accessed 26 December 2015).

Vorobiev V., Protopriest (1997) Pokayanie, ispoved', dukhovnoe rukovodstvo [Repentance, Confession, Spiritual Guidance], Moscow: Svet pravoslaviya.

Vorobiev V., Protopriest (200o) Pastyrskoe sluzhenie v Russkoi Pravoslavnoi Tserkvi. XX v. [Pastoral Service in Russian Orthodox Church, 2oth Century]. Pravoslavnaya entsiklopediya. Vvodnyj tom [Orthodox Christian Encyclopedia, Introductory Volume], Moscow: Pravoslavnaya entsiklopediya, pp. 295-304.

Wilson B. (1966) Religion in Secular Society: A Sociological Comment, London: Watts.

Zabaev I. (2011) "Sakral'nyj individualism” i obshchina v sovremennom russkom pravoslavii ["Sacred Individualism" and Community in Contemporary Russian Orthodox Christianity]. Prikhod i obshchina v sovremennom pravoslavii: kornevaia sistema rossijskoi religioznosti [Parish and Comminity in Contemporary Russian Orthodox Christianity: The Root System of Russian Religiosity] (eds. A. Agadzanyan, K. Russele), Moscow: Ves mir, pp. 341-354.

Zabaev I., Prutskova E. (2012) Obshchina pravoslavnogo khrama: prostranstvennaia lokalizatsiia i faktory formirovaniia (na primere g. Moskvy) [Community of an Or- 
thodox Church: Spatial Localization and the Forming Factors (Using the Example of Moscow)]. Vestnik PSTGU. Series I: Theology, Philosophy, no 3, pp. 57-67.

Zabaev I., Prutskova E. (2013) Sotsial'naya set' pravoslavnoj prikhodskoj obshhiny: vozmozhnosti primeneniya analiza sotsial'nykh setej v sotsiologii religii [Social Network of Orthodox Parish Community: Opportunities for Applying Social Network Analysis in the Sociology of Religion]. Vestnik PSTGU. Series I: Theology. Philosophy, no 4, pp. 120-136.

Zabaev I., Oreshina D., Prutskova E. (2010) Problemy metodologii organizatsii sotsial'noj deyatel'nosti na prikhodakh Russkoj Pravoslavnoj Tserkvi v nachale XXI v. [Problems in the Methodology of Organizing Social Work at the Parishes of the Russian Orthodox Church in the Beginning of the 21st Century]. Available at: http://socrel.pstgu.ru/ wp-content/uploads/2013/o9/WP_2010-08.pdf (accessed 29 December 2015).

Zabaev I., Oreshina D., Prutskova E. (2012) Tri moskovskikh prikhoda: osnovnye sotsialnodemograficheskie pokazateli $i$ ustanovki predstavitelej obshchin krupnykh prikhodov [Three Moscow Parishes: Main Social-Demographic Indicators and Attitudes of the Representatives of Large Parish Communities], Moscow: PSTGU.

Zabaev I., Oreshina D., Prutskova E. (2014) Sotsial'nyi kapital russkogo pravoslaviya v nachale XXI v.: issledovanie s pomoshch'yu metodov sotsial'no-setevogo analiza [Social Capital of the Russian Orthodox Christianity in the Beginning of the 21st Century: The Study Using the Methods of Social-Network Analysis]. State, Religion and Church in Russia and Worldwide, no 1, pp. 40-66.

Zorkaya N. (2009) Pravoslavie v bezreligioznom obshchestve [Orthodox Christianity in a Non-religious Society]. The Russian Public Opinion Herald, no 2, pp. 65-84.

Zulehner P. M. (2001) Priester im Modernisierungsstress: Forschungsbericht der Studie PRIESTER 200o, Ostfildern: Schwabenverlag.

\section{Временная структура деятельности священников и субстантивные эффекты религиозной жизни в современной России}

\section{Николай Емельянов}

Протоиерей, научный сотрудник научной лаборатории «Социология религии» Православного СвятоТихоновского гуманитарного университета

Адрес: Лихов пер., д. 6, стр. 1, г. Москва, Российская Федерация 127051

Email:pr_nikolay@mail.ru

В данной статье с позиции теории религиозного рынка обсуждается проблема разрыва между показателями религиозной самоидентификации (69\%) и показателями вовлеченности в религиозные практики (3\%), а также связанное с этим отсутствие следствий религиозности на данных массовых опросов в современном российском обществе. Напротив, влияние 
религиозности на ценности, социальные болезни, семейное и репродуктивное поведение оказывается очень сильным для практикующих православных (И. Забаев, Д. Орешина, Е. Пруцкова). Существующие исследования, посвященные анализу разрыва между показателями самоидентификации и вовлеченности, интерпретируют ситуацию с позиции теории секуляризации. В статье предложено переосмысление религиозных процессов В России со стороны предложения. На основании теории религиозной экономики (Р. Старк, В. Бейнбридж, Р. Финке, Л. Ианнаконе и др.) предлагается модель религиозного рынка для стран с религиозной монополией. Моделируются различные оценки религиозного предложения в зависимости от среднего времени исповеди. В статье показано, что существенным ограничивающим фактором религиозного предложения в России остается недоступность священника для регулярного участия в исповеди. На основании модели религиозного предложения предлагается альтернативная по отношению к существующему научному дискурсу гипотеза для объяснения разрыва между православной самоидентификацией и вовлеченностью в практики исповеди и причастия в современной России.

Ключевые слова: измерения религиозности, секуляризация, теория рынка религий, модель религиозного предложения, бюджет времени священника, социальные эффекты религиозности, Русская Православная церковь 